\title{
Persepsi dan Perilaku Membaca Label Pangan dan Informasi Gizi pada Siswa SMK Wijaya Kusuma
}

\author{
Lulu'ul Badriyah ${ }^{1}$, Abdullah Syafei ${ }^{2}$ \\ ${ }^{1}$ Program Studi Sarjana Gizi STIKES Indonesia Maju \\ ${ }^{2}$ Program Studi Kesehatan Masyarakat STIKES Indonesia Maju \\ Jl.Harapan 50 Lenteng Agung Jagakarsa Jakarta Selatan 12610 \\ E-mail: ${ }^{1}$ lulubadriyah91@gmail.com, ${ }^{2}$ syafei06@gmail.com
}

\begin{abstract}
Abstrak
Informasi pada label kemasan makanan menentukan apakah makanan bergizi, berkualitas dan aman dikonsumsi. Label makanan juga berperan penting terhadap keputusan konsumen dalam membeli makanan, namun perilaku membaca label pangan kemasan di Indonesia masih cukup rendah. Penelitian ini bertujuan mengetahui perilaku membaca label pangan dan informasi gizi pada pangan kemasan pada siswa SMK Wijaya Kusuma. Lokasi penelitian dilakukan di SMK Wijaya Kusuma Jakarta Selatan dengan desain studi cross sectional. Penelitian ini dilakukan dari Juni - September 2019 dengan jumlah sampel 150 orang. Data dianalisis secara univariat dan bivariat menggunakan chi square. Hasil penelitian didapatkan $68,7 \%$ responden berusia 16 tahun, $56,7 \%$ responden mempunyai uang saku $<$ Rp.500.000, 64\% responden pernah mendapatkan informasi dengan label pangan dan informasi gizi, $48,7 \%$ responden yang mempunyai pengetahuan tentang label pangan dan informasi gizi kurang, 62,7\% responden mempunyai persepsi positif terhadap label pangan dan informasi gizi, 68,7\% responden yang mempunyai kemampuan membaca label gizi sangat kurang, dan 43,3\% responden yang kadang-kadang menggunakan label gizi sebagai acuan pembelian makanan kemasan. Hasil uji statistik menunjukkan hanya pengetahuan tentang label pangan dan informasi gizi yang berhubungan dengan jenis kelamin. Disarankan meningkatkan pengetahuan siswa dalam membaca label informasi gizi.
\end{abstract}

Kata kunci: Informasi gizi, Label, Persepsi

\begin{abstract}
The information on food packaging labels determines whether food is nutritious and safe for consumption. Food labels also play an important role in consumers' decision to buy food, meanwhile the behavior of reading food labels in Indonesia is still quite low. This study aims to determine the behavior of reading food labels and nutrition fact on packaged food among students at SMK Wijaya Kusuma. This study was conducted from June to September 2019 with 150 sample and using cross sectional design. Data were analyzed using chi square method. The results showed $68.7 \%$ of respondents were 16 years, $56.7 \%$ of respondents had allowance less than Rp.500,000, 64\% of respondents had received information with food labels and nutrition fact, $48.7 \%$ of respondents had not known food labels and nutrition fact, $62.7 \%$ of respondents had a positive perception of food labels and nutrition fact, $68.7 \%$ of respondents had very poor ability to read nutrition fact, and $43.3 \%$ of respondents sometimes used nutritional fact as a reference for purchases the food. The bivariate analysis showed that there was association between gender with food labels and nutritional fact comprehension. It is recommended to increase students' comprehension in reading nutrition fact.
\end{abstract}

Keywords : Label, Nutrition fact, Perception 


\section{Pendahuluan}

Transisi epidemiologi menyebabkan terjadinya pergeseran pola penyakit, dimana terjadi peningkatan penyakit kronis seperti hipertensi, diabetes mellitus, jantung dan obesitas. Salah satu kontribusi utama penyakit tersebut adalah pola hidup yang tidak sehat seperti pola makan yang salah dan kurangnya aktifitas fisik. Seiring perkembangan zaman, masyarakat juga mengalami pergeseran pola makan. Masyarakat beralih ke makanan siap saji dan kemasan karena dianggap lebih praktis dan terjangkau. ${ }^{2}$ Dengan demikian, informasi pada kemasan pangan memainkan peranan penting apakah makanan tersebut bergizi, berkualitas dan aman dikonsumsi. Pelabelan makanan juga berperan penting terhadap keputusan konsumen dalam membeli makanan. ${ }^{3-5}$

Membiasakan membaca label pada kemasan pangan merupakan salah satu pesan umum dari pesan Pedoman Gizi Seimbang (PGS). Semua keterangan yang rinci pada label makanan yang dikemas sangat membantu konsumen untuk mengetahui bahan-bahan yang terkandung dalam makanan tersebut. Selain itu dapat memperkirakan bahaya yang mungkin terjadi pada konsumen yang berisiko tinggi karena punya penyakit tertentu. Oleh karena itu dianjurkan untuk membaca label pangan yang dikemas terutama keterangan tentang informasi kandungan zat gizi dan tanggal kadaluarsa sebelum membeli atau mengonsumsi makanan tersebut. ${ }^{6}$ Namun, informasi gizi biasanya tidak dimanfaatkan konsumen. ${ }^{7}$ Banyak yang menganggap bahwa label informasi gizi terlalu ilmiah dan sulit dipahami. ${ }^{8}$

Hasil penelitian menunjukkan bahwa perhatian masyarakat kurang perhatian terhadap label pangan dan informasi gizi. Penelitian pada mahasiswa pada Fakultas Ilmu Kesehatan Universitas Esa Unggul hanya $69,7 \%$ yang mempunyai kebiasaan membaca label. ${ }^{9}$ Sementara, siswa SMA di Kota Bogor yang memperhatikan label kemasan pangan sebelum membeli makanan hanya berjumlah $61,2 \% .^{10}$
Penelitian di Semarang menunjukkan hanya 55\% responden yang kadang-kadang membaca informasi gizi. ${ }^{8}$ Penelitian di Universitas Indonesia hanya 39,1\% mahasiswa membaca label informasi gizi dan $38,9 \%$ yang membaca label komposisi. $^{11}$ Sementara mahasiswa Universitas Airlangga menunjukkan sebesar 53,06\% respoden jarang atau tidak pernah membaca informasi nilai gizi pada label pangan. ${ }^{12}$

Banyak faktor yang turut berperan mempengaruhi seseorang untuk menggunakan label makanan, diantaranya pendidikan gizi, ${ }^{7}$ usia, tingkat pendidikan dan pendapat bulanan. Responden dengan usia lebih tua, berpendidikan lebih tinggi dan berpendapatan lebih tinggi cenderung membaca dan menggunakan label informasi nilai gizi. ${ }^{8,13}$ Seseorang yang mempunyai kebiasaan makan sehat juga lebih besar menggunakan informasi nilai gizi. $^{14}$

Dapat disimpulkan bahwa perilaku membaca label pangan kemasan di Indonesia masih cukup rendah. Penelitian terkait label pangan dan informasi gizi pada remaja SMA juga masih jarang. Padahal remaja merupakan kelompok yang rentan gizi. Dengan demikian, penelitian ini bertujuan mengetahui perilaku membaca label pangan dan informasi gizi pada pangan kemasan pada siswa SMK Wijaya Kusuma.

\section{Metode}

Penelitian ini menggunakan desain studi cross sectional atau potong lintang. Studi cross sectional merupakan pengumpulan data variabel dependen dan variabel independen yang terjadi pada objek yang diteliti, diukur dalam waktu yang bersamaan. Lokasi penelitian dilakukan di SMK Wijaya Kusuma Jakarta Selatan. Penelitian ini dilakukan mulai Juni sampai September 2019. Populasi dalam penelitian ini adalah seluruh siswa SMK Wijaya Kusuma dengan jumlah sampel 150 orang. Pengambilan sampel dilakukan dengan menggunakan simple random 
sampling. Kriteria inklusi adalah siswa yang bersedia menjadi responden penelitian dan hadir pada saat penelitian berlangsung dan kriteria eksklusi adalah siswa yang mengundurkan diri dan tidak hadir atau sakit pada saat penelitian berlangsung.

Responden diminta untuk mengisi kuisioner mengenai perilaku dan persepsi responden terhadap label pangan dan informasi gizi. Persepsi responden terkait label pangan dan informasi nilai gizi dilakukan dengan memilih jawaban dari skala $1-4$. Dimana skala $1=$ sangat tidak setuju, skala $2=$ tidak setuju, skala $3=$ setuju, dan skala $4=$ sangat tidak setuju. Analisis data persepsi dilakukan dengan menjumlahkan skor kemudian dikategorikan menjadi 2 , yaitu $\geq$ median dan < median. Median persepsi responden terhadap label pangan dan informasi gizi adalah 39.

Analisis univariat digunakan untuk mendapatkan gambaran distribusi frekuensi masing-masing variable dan disajikan dalam bentul Tabel frekuensi. Uji chi square dengan tingkat kepercayaan 95\% digunakan untuk mengalisis hubungan antara usia, uang saku, paparan informasi, pengetahuan, persepsi, kemampuan membaca, dan menggunakan label sebagai acuan membeli makanan dengan jenis kelamin.

\section{Hasil}

Tabel 1. Hubungan Perilaku Membaca Label Pangan dan Informasi Gizi dengan Jenis Kelamin

\begin{tabular}{|c|c|c|c|c|c|c|}
\hline \multirow{2}{*}{ Variabel } & \multirow{2}{*}{ Kategori } & \multicolumn{2}{|c|}{ Laki-laki } & \multicolumn{2}{|c|}{ Perempuan } & \multirow{2}{*}{ Pvalue } \\
\hline & & $\mathbf{n}$ & $\%$ & n & $\%$ & \\
\hline \multirow[t]{3}{*}{ Usia } & 15 tahun & 6 & 25 & 18 & 75 & 0,11 \\
\hline & 16 tahun & 50 & 48,5 & 53 & 51,5 & \\
\hline & $\geq 17$ tahun & 11 & 47,8 & 12 & 52,2 & \\
\hline \multirow[t]{3}{*}{ Uang saku } & $<$ Rp. 500.000 & 38 & 44,7 & 47 & 55,3 & 0,07 \\
\hline & Rp500.000-Rp1.000.000 & 25 & 41 & 36 & 59 & \\
\hline & $>\mathrm{Rp} 1.000 .000$ & 4 & 100 & 0 & 0 & \\
\hline \multirow{5}{*}{$\begin{array}{l}\text { Paparan } \\
\text { informasi } \\
\text { Pengetahuan }\end{array}$} & Tidak pernah & 19 & 35,2 & 35 & 64,8 & 0,11 \\
\hline & Pernah & 48 & 50 & 48 & 50 & \\
\hline & Kurang & 45 & 61,6 & 28 & 38,4 & $0,01 *$ \\
\hline & Cukup & 20 & 31,3 & 44 & 68,8 & \\
\hline & Baik & 2 & 15,4 & 11 & 84,6 & \\
\hline \multirow{2}{*}{ Persepsi } & Negatif & 23 & 41,1 & 33 & 58,9 & 0,61 \\
\hline & Positif & 44 & 46,8 & 50 & 53,2 & \\
\hline \multirow{4}{*}{$\begin{array}{l}\text { Kemampuan } \\
\text { membaca label }\end{array}$} & Sangat kurang & 49 & 47,6 & 54 & 52,4 & 0,70 \\
\hline & Kurang & 10 & 35,7 & 18 & 64,3 & \\
\hline & Baik & 7 & 43,8 & 9 & 56,3 & \\
\hline & Sangat baik & 1 & 33,3 & 2 & 66,7 & \\
\hline \multirow{5}{*}{$\begin{array}{l}\text { Label sebagai } \\
\text { acuan membeli } \\
\text { makanan }\end{array}$} & Tidak pernah & 11 & 50 & 11 & 50 & 0,19 \\
\hline & Jarang & 15 & 57,7 & 11 & 42,3 & \\
\hline & Kadang-kadang & 24 & 36,9 & 41 & 63,1 & \\
\hline & Sering & 12 & 57,1 & 9 & 42,9 & \\
\hline & selalu & 5 & 31,3 & 11 & 68,8 & \\
\hline
\end{tabular}

Keterangan: *signifikan pada $\alpha$ (alpha) $=5 \%$

Dari tabel 1 diketahui bahwa Lebih dari separuh $(55,3 \%)$ responden berjenis kelamin perempuan dan sebanyak $44,7 \%$ berjenis kelamin laki-laki. Sebanyak
$68,7 \%$ responden berusia 16 tahun dengan jumlah laki-laki $48,5 \%$ dan perempuan $51,5 \%$. Sementara jumlah responden berusia 15 tahun hanya $16 \%$ dan $>17$ tahun 
hanya $15,3 \%$. Lebih dari separuh $(56,7 \%)$ responden mempunyai uang saku $<$ Rp.500.000 dengan rincian laki-laki sebanyak $41 \%$ dan perempuan sebanyak $56,7 \%$. Responden yang mempunyai uang saku >Rp.1000.000 hanya 4 orang atau 2,7. Sebanyak $64 \%$ responden pernah mendapatkan informasi dengan label pangan dan informasi gizi. Jumlah responden laki-laki dan perempuan yang pernah mendapatkan paparan informasi sama. Responden yang mempunyai pengetahuan tentang label pangan dan informasi gizi baik (skor >76) hanya 8,7\% dengan jumlah perempuan 11 orang dan laki-laki 2 orang. Sementara responden yang mempunyai pengetahuan tentang label pangan dan informasi gizi kurang sebanyak $48,7 \%$ dan cukup $42,7 \%$. Lebih dari separuh $(62,7 \%)$ responden mempunyai persepsi positif terhadap label pangan dan informasi gizi. Jumlah responden perempuan yang mempunyai persepsi positif sebanyak $53,2 \%$ dan lakilaki sebanyak 46,8\%. Responden yang mempunyai kemampuan membaca label gizi sangat baik hanya $2 \%$ dan baik hanya $10,7 \%$. Sementara responden yang mempunyai kemampuan membaca label gizi sangat kurang sebanyak $68,7 \%$ dengan jumlah laki-laki 47,6\% dan perempuan $52,4 \%$. Responden yang kadang-kadang menggunakan label gizi sebagai acuan pembelian makanan kemasan sebanyak 43,3\% (laki-laki 36,9\% dan perempuan $63,1 \%$ ) dan responden yang selalu menjadikan label informasi gizi sebagai acuan pembelian hanya $10,7 \%$. Hasil uji statistik menunjukkan ada hanya jenis kelamin yang berhubungan dengan pengetahuan tentang label pangan dan informasi gizi.

Tabel 2. Distribusi Responden Berdasarkan Tingkat Keseringan Membaca Label Pangan

\begin{tabular}{|c|c|c|c|c|c|c|c|c|c|c|}
\hline \multirow{3}{*}{ Label Pangan } & \multicolumn{10}{|c|}{ Tingkat Keseringan } \\
\hline & \multicolumn{2}{|c|}{ Tidak pernah } & \multicolumn{2}{|c|}{ Jarang } & \multicolumn{2}{|c|}{ Kadang-kadang } & \multicolumn{2}{|c|}{ Sering } & \multicolumn{2}{|c|}{ Selalu } \\
\hline & $\mathbf{n}$ & $\%$ & $\mathbf{n}$ & $\%$ & $\mathbf{n}$ & $\%$ & $\mathbf{n}$ & $\%$ & $\mathrm{n}$ & $\%$ \\
\hline Nama produk & 3 & 2 & 4 & 2,7 & 20 & 13,3 & 31 & 20,7 & 92 & 61,3 \\
\hline Komposisi & 4 & 2,7 & 28 & 18,7 & 70 & 46,7 & 30 & 20 & 18 & 12 \\
\hline Berat bersih & 10 & 6,7 & 41 & 27,3 & 63 & 42 & 16 & 10,7 & 20 & 13,3 \\
\hline Kadaluarsa & 6 & 4 & 2 & 1,3 & 14 & 9,3 & 33 & 22 & 95 & 63,3 \\
\hline Label halal & 3 & 2 & 2 & 1,3 & 13 & 8,7 & 30 & 20 & 102 & 68 \\
\hline Takaran saji & 17 & 11,3 & 36 & 24 & 60 & 40 & 17 & 11,3 & 20 & 13,3 \\
\hline Jumlah sajian & 21 & 14 & 40 & 26,7 & 53 & 35,3 & 16 & 10,7 & 20 & 13,3 \\
\hline$\% \mathrm{AKG}$ & 42 & 28 & 41 & 27,3 & 45 & 30 & 7 & 4,7 & 15 & 10 \\
\hline
\end{tabular}

Tabel 3. Distribusi Responden Berdasarkan Tingkat Keseringan Membaca Label Informasi Gizi pada Siswa SMK Wijaya Kusuma Jakarta Tahun 2019 (n=150)

\begin{tabular}{|c|c|c|c|c|c|c|c|c|c|c|}
\hline \multirow{3}{*}{$\begin{array}{c}\text { Label } \\
\text { Informasi Nilai } \\
\text { Gizi }\end{array}$} & \multicolumn{10}{|c|}{ Tingkat Keseringan } \\
\hline & \multicolumn{2}{|c|}{ Tidak pernah } & \multicolumn{2}{|c|}{ Jarang } & \multicolumn{2}{|c|}{ Kadang-kadang } & \multicolumn{2}{|c|}{ Sering } & \multicolumn{2}{|c|}{ Selalu } \\
\hline & $\mathbf{n}$ & $\%$ & $\mathbf{n}$ & $\%$ & $\mathbf{n}$ & $\%$ & $\mathbf{n}$ & $\%$ & $\mathbf{n}$ & $\%$ \\
\hline Kalori & 10 & 6,7 & 46 & 30,7 & 53 & 35,3 & 22 & 14,7 & 19 & 12,7 \\
\hline Kolesterol & 16 & 10,7 & 43 & 28,7 & 54 & 36 & 25 & 16,7 & 12 & 8 \\
\hline Lemak & 10 & 6,7 & 42 & 28 & 51 & 34 & 30 & 20 & 17 & 11,3 \\
\hline Vitamin & 9 & 6 & 26 & 17,3 & 49 & 32,7 & 32 & 21,3 & 34 & 22,7 \\
\hline Protein & 7 & 4,7 & 27 & 18 & 51 & 34 & 34 & 22,7 & 31 & 20,7 \\
\hline Natrium & 15 & 10 & 46 & 30,7 & 48 & 32 & 25 & 16,7 & 16 & 10,7 \\
\hline Gula & 15 & 10 & 34 & 22,7 & 50 & 33,3 & 25 & 16,7 & 26 & 17,3 \\
\hline Serat & 26 & 17,3 & 43 & 28,7 & 54 & 36 & 15 & 10 & 12 & 8 \\
\hline Kalsium & 12 & 8 & 39 & 26 & 52 & 34,7 & 24 & 16 & 23 & 15,3 \\
\hline
\end{tabular}


Pada tabel 2 terlihat bahwa label pangan yang selalu diperhatikan responden paling banyak adalah label halal (68\%). Kemudian label pangan yang selalu diperhatikan adalah tanggal kadaluarsa $(63,3 \%)$ dan nama produk $(61,3 \%)$. Label pangan yang sering diperhatikan responden paling banyak adalah tanggal kadaluarsa $(22,0 \%)$. Sedangkan label pangan yang kadang-kadang diperhatikan responden paling banyak adalah komposisi bahan (42\%). Sementara label pangan yang jarang diperhatikan responden adalah persentase AKG $(27,3 \%)$ dan berat bersih $(27,3 \%)$. Dan, label pangan yang tidak pernah diperhatikan responden paling banyak adalah persentase AKG $(28,0 \%)$.

Tabel 3 menyebutkan bahwa tingkat keseringan responden membaca label informasi nilai gizi. Urutan informasi gizi yang selalu adalah vitamin (22,7\%), protein $(20,7 \%)$, gula $(17,3 \%)$, kalsium $(15,3 \%)$, kalori $(12,7 \%)$, lemak $(11,3 \%)$, natrium $(10,7 \%)$, kolesterol $(8,0 \%)$ dan serat pangan $(8,0 \%)$. Sementara urutan informasi gizi yang jarang dibaca responden adalah natrium $(30,7 \%)$, kalori $(30,7 \%)$, kolesterol $(28,7 \%)$, serat pangan $(28,7 \%)$, lemak $(28,0 \%)$, kalsium $(26,0 \%)$, gula $(22,7 \%)$, protein $(18,0 \%)$ dan vitamin $(17,3 \%)$

\section{Pembahasan}

Peraturan Pemerintah Nomor 69 Tahun 1999 tentang Label dan Iklan Pangan menyatakan bahwa pencantuman kadungan gizi pada label wajib dilakukan bagi pangan kemasan yang disertai pernyataan bahwa pangan mengandung vitamin, mineral dan zat gizi lainnya yang ditambahkan dan pangan yang disyaratkan berdasarkan peraturan perundangundangan. ${ }^{15}$ Pemberian label pangan ini bertujuan untuk memberikan informasi yang benar dan jelas kepada masyarakat mengenai produk pangan kemasan sebelum membeli atau mengonsumsinya.

Penelitian pada anak SMA di Kota Bogor menunjukkan label kemasan pangan yang paling diperhatikan responden adalah label halal (36,5\%), waktu kadaluarsa $(34,9 \%)$, nama produk $(20,6 \%)$, dan komposisi makanan (7,9\%). Sebanyak $88,9 \%$ responden memutuskan untuk tidak jadi membeli makanan jika tidak menemukan label kemasan pangan yang dicarinya dan hanya $11,1 \%$ yang tetap membeli makanan walaupun tidak menemukan label kemasan pangan yang dicarinya. ${ }^{10}$ Sementara, pada penelitian ini label pangan yang selalu diperhatikan responden paling banyak adalah label halal (68\%), tanggal kadaluarsa $(63,3 \%)$, dan nama produk $(61,3 \%)$. Sementara label yang jarang diperhatikan adalah persentase AKG (27,3\%), berat bersih $(27,3 \%)$, dan jumlah sajian (26,7\%).

Responden penelitian yang pernah mendapatkan informasi tentang label pangan dan informasi gizi sebanyak 64\%. Hal yang sama juga terjadi pada siswa SMK Mandalahayu, sebanyak 95,2\% responden pernah mendapat informasi dan hanya $4,8 \%$ responden yang tidak pernah mendapatkan informasi label informasi nilai gizi. Televisi merupakan media cetak/elektronik yang paling banyak $(71,2 \%)$ memberikan informasi mengenai label gizi oleh responden. Orang tua juga paling sering $(61,9 \%)$ memberikan informasi tentang label gizi kepada responden. ${ }^{16}$ Sementara, penelitian pada mahasiswa Fakultas Ilmu Kesehatan Universitas Esa Unggul pada 142 responden yang pernah mendapatkan paparan sumber informasi tentang label informasi gizi sebanyak $92,3 \%$ dan sumber informasi didapatkan paling sering dari internet. Paparan sumber informasi dapat memberikan dampak positif karena dapat meningkatkan pengetahuan tentang label pangan. Namun, penelitian tersebut menemukan tidak ada hubungan signifikan antara paparan sumber informasi dengan kebiasaan membaca label informasi nilai gizi. ${ }^{9}$

Penelitian menunjukkan paling banyak $(48,7 \%)$ responden yang mempunyai pengetahuan tentang label pangan dan informasi gizi dengan skor 
kurang atau dibawah skor 55. Sementara, responden yang mempunyai pengetahuan tentang label pangan dan informasi gizi dengan skor baik atau di atas 76 jumlahnya sangat sedikit, yaitu hanya $8,7 \%$. Sama halnya dengan studi pada mahasiswa, ditemukan bahwa responden yang mempunyai pengetahuan tentang label pangan lebih banyak yang berpengetahuan kurang $(66,2 \%)$ dibandingkan yang berpengetahuan baik $(33,8 \%)$. Berbeda dengan penelitian lain yang dilakukan pada 68 orang usia 17 sampai 65 tahun di Pasar Swalayan ADA Setiabudi Semarang. Responden yang mempunyai pengetahuan baik sudah cukup banyak yaitu $41,2 \%$ sedangkan responden yang mempunyai pengetahuan tentang label pangan kurang hanya $10,3 \% .^{17}$ Responden yang mempunyai pengetahuan baik berhubungan signifikan dengan kebiasaan membaca label informasi gizi. ${ }^{9}$ Pengetahuan gizi yang baik membuat responden lebih memahami dan membaca label gizi sehingga lebih patuh dalam membaca label informasi gizi dan komposisi gizi. ${ }^{11}$ Pengetahuan merupakan domain terbentuknya perilaku kesehatan, sehingga untuk membiasakan perilaku membaca label pangan dan informasi gizi perlu meningkatkan pengetahuan konsumen.

Hasil penelitian menunjukkan ada hubungan signifikan pengetahuan antara laki-laki dan perempuan. Sebagian besar penelitian menemukan bahwa perempuan lebih menggunakan informasi label gizi dibandingkan laki-laki. Banyak laki-laki yang menganggap bahwa informasi label gizi kurang berguna bagi pilihan makanan dan berdampak pada kesehatannya. ${ }^{18}$ Hasil penelitian terdahulu menunjukkan ada hubungan positif dan nyata antara jenis kelamin dengan pengetahuan tentang label informasi gizi. Responden perempuan memiliki pengetahuan yang lebih baik sebesar 9,724 poin dibandingkan laki-laki. Pengetahuan tentang label informasi gizi yang dimiliki responden berjenis kelamin perempuan lebih baik dibandingkan laki- laki. $^{15}$ Penelitian di Jakarta juga menunjukkan bahwa perempuan cenderung patuh membaca label gizi dibandingkan laki-laki. ${ }^{19}$

Responden yang mempunyai kemampuan membaca label gizi sangat baik sangat sedikit yaitu hanya $2 \%$ dan yang baik hanya $10,7 \%$. Sementara responden yang mempunyai kemampuan membaca label gizi sangat kurang sebanyak $68,7 \%$. Hal ini menunjukkan bahwa kemampuan siswa dalam membaca label gizi masih sangat rendah. Begitu juga penelitian pada mahasiswa di salah satu perguruan tinggi di Jakarta, ketidakmampuan mambaca label gizi dengan baik menjadi masalah yang dihadapi mahasiswa tersebut. Responden yang mempunyai kemampuan baik dalam membaca label lebih tinggi $(69,7 \%)$ dibandingkan yang kurang (30,3\%). ${ }^{9}$ Kemampuan membaca label gizi menunjukkan kemampuan responden dalam membaca informasi nilai gizi yang tertera pada informasi nilai gizi. Jika kemampuan responden dalam membaca label informasi gizi baik, akan mempermudah responden dalam memahami informasi yang tertera dalam makanan kemasan. Namun, studi pada 67 responden ibu rumah tangga di Pasar Basah Mandonga Kota Kendari menunjukkan ibu rumah tangga yang mempunyai kemampuan membaca label baik lebih tinggi $(79,1 \%)$ dibandingkan ibu yang kemampuannya kurang $(20,9 \%){ }^{20}$ Usia juga mempengaruhi penggunaan label gizi. Penelitian menunjukkan bahwa responden yang lebih tua (usia $\geq 55$ tahun) lebih memperhatikan label gizi dibandingkan responden yang lebih muda. ${ }^{4}$ Orang yang lebih tua cenderung lebih sering menggunakan label informasi nilai gizi dibandingkan dengan orang yang lebih muda. Orang yang lebih tua memiliki pola makan yang lebih ketat sehingga cenderung lebih sering menggunakan label informasi gizi sebagai pertimbangan kesehatan. ${ }^{8}$ Penelitian pada mahasiswa di Surabaya menunjukkan yang jarang dan 
tidak pernah membaca informasi gizi. Mahasiswa memilih makanan bukan karena alasan kesehatan dan informasi gizi yang terkandung dalam makanan tersebut. $^{12}$ Siswa SMA di Jakarta tidak membaca label informasi nilai gizi dikarenakan rasa malas, tidak tertarik, dan tidak mengerti dalam membaca label informasi gizi. ${ }^{19}$

Informasi gizi yang selalu selalu dibaca responden paling banyak adalah vitamin $(22,7 \%)$ dan paling sedikit adalah serat pangan $(8,0 \%)$. Penelitian lain menggambarkan zat gizi paling banyak selalu dibaca yaitu lemak total sebanyak 35 responden $(18,6 \%)$ dan paling sedikit selalu dibaca yaitu natrium yang dibaca oleh 6 responden $(3,2 \%) .{ }^{19}$ Penelitian lain menemukan bahwa informasi gizi yang paling banyak dibaca oleh responden adalah kandungan vitamin/mineral dan lemak, sedangkan informasi tentang serat dan sodium/natrium merupakan informasi yang tidak dibaca oleh responden. ${ }^{16}$ Studi di Jogjakarta mengungkapkan bahwa alasan utama responden tidak membaca label gizi karena lupa dan kesulitan memahami informasi label tersebut. $^{2}$

Meskipun tidak berhubungan signifikan, dalam penelitian ini menunjukkan bahwa perempuan cenderung mempunyai kemampuan membaca label gizi lebih baik dibandingkan laki-laki. Beberapa penelitian juga menunjukkan bahwa gender memiliki pengaruh dalam penggunaan label pangan. ${ }^{4}$ Studi National Health and Nutrition Examination Survey (2005-2006) di United States (US) juga menunjukkan perempuan lebih memperhatikan label pangan dibandingkan laki-laki. ${ }^{13}$

Penelitian menunjukkah lebih dari separuh $(62,7 \%)$ responden mempunyai persepsi positif terhadap label pangan dan informasi gizi. Sejalan dengan penelitian sebelumnya di Jakarta bahwa responden yang mempunyai persepsi baik terhadap label gizi cukup tinggi, yaitu sebesar $62,6 \%$. Persepsi merupakan salah satu faktor yang mempengaruhi timbulnya perilaku kesehatan. Semakin positif persepsi seseorang terhadap label gizi maka akan semakin baik pula perilaku seseorang dalam membaca label gizi. ${ }^{21}$ Penelitian Purnama, juga mengatakan bahwa sebagian besar persepi responden terhadap kandungan gizi pada produk makanan/minuman kemasan adalah hal yang penting (92,5\%). Namun, hasil penelitian menyatakan tidak terdapat hubungan signifikan antara persepsi terhadap kandungan zat gizi produk dengan kepatuhan membaca label informasi nilai gizi. ${ }^{16}$

Perilaku konsumen mengenai label pangan dan label gizi ini dapat mempengaruhi seseorang dalam mengambil keputusan untuk membeli produk pangan. ${ }^{21}$ Namun, pada penelitian ini responden yang kadang-kadang menjadikan label gizi sebagai acuan pembelian makanan kemasan hanya $43,3 \%$.

\section{Kesimpulan}

Berdasarkan hasil penelitian, disimpulkan bahwa $64 \%$ responden pernah mendapatkan informasi tentang label pangan dan informasi gizi, 48,7\% responden mempunyai pengetahuan tentang label pangan dan informasi gizi kurang, $62,7 \%$ responden mempunyai persepsi positif terhadap label pangan dan informasi gizi, $68,7 \%$ responden mempunyai kemampuan membaca label gizi sangat kurang dan hanya $10,7 \%$ responden yang selalu menjadikan label informasi gizi sebagai acuan pembelian. Hasil uji statistik menunjukkan hanya pengetahuan tentang label pangan dan informasi gizi yang berhubungan dengan jenis kelamin. Sementara, label pangan yang paling banyak selalu diperhatikan responden adalah label halal. Sedangkan informasi gizi yang selalu dibaca responden adalah vitamin dan informasi gizi yang jarang dibaca responden adalah natrium dan kalori. Oleh karena itu pihak sekolah diharapkan dapat meningkatkan 
pengetahuan kepada siswa SMK Wijaya Kusuma tentang cara membaca label pangan khususnya informasi nilai gizi makanan kemasan dan kandungan gizi makanan kemasan mengingat kemampuan membaca label informasi gizi siswa masih sangat kurang.

\section{Daftar Pustaka}

1. Handajani A, Roosihermiatie B, Maryani H. Faktor-faktor yang Berhubungan dengan Pola Kematian Pada Penyakit Degeneratif di Indonesia. Bul Penelit Sist Kesehat 2010; 13: 42-53.

2. Palupi IR, Naomi ND, Susilo J. Penggunaan Label Gizi dan Konsumsi Makanan Kemasan Pada Anggota Persatuan Diabetisi Indonesia Unit RS Kota Yogyakarta. J Kesehat Masy 2017; 11: 1-12.

3. Bandara BES, De Silva DAM, Maduwanthi $\mathrm{BCH}$, et al. Impact of Food Labeling Information on Consumer Purchasing Decision: With Special Reference to Faculty of Agricultural Sciences. Procedia Food Sci 2016; 6: 309-313.

4. Azman N, Sahak SZ. Nutritional Label and Consumer Buying Decision: A Preliminary Review. Procedia - Soc Behav Sci 2014; 130: 490-498.

5. Wills JM, Schmidt DB, Pillo-Blocka F, et al. Exploring global consumer attitudes toward nutrition information on food labels. Nutr Rev; 67. Epub ahead of print 2009. DOI: 10.1111/j.1753-4887.2009.00170.x.

6. Kemenkes. Pedoman Gizi Seimbang. Kementeri Kesehat RI 2014; 99.

7. Miller LMS, Cassady DL. The effects of nutrition knowledge on food label use. A review of the literature. Appetite 2015; 92: 207-216.

8. Asgha B. Analisa Penggunaan Label Informasi Nilai Gizi pada Produk Pangan oleh Konsumen di Kota Semarang. J Bul Stud Ekon 2016; 21: 128-135.

9. Rahayu ST, Jus'at I, Melani V. Pengetahuan Gizi Sebagai Faktor Dominan Kebiasaan Membaca Label Informasi Gizi Pada Mahasiswa Fakultas Ilmu - Ilmu Kesehatan Universitas Esa Unggul”. EUE Digit Repos 2016; 41: 1-8.

10. Susanto. Pengaruh Label Kemasan Pangan Terhadap Keputusan Siswa Sekolah Menengah Atas Dalam Membeli Makanan Ringan Di Kota Bogor. Institut Pertanian Bogor, 2008.
11. Zahara S, Tryanti. Kepatuhan Membaca Label Informasi Zat Gizi di Kalangan Mahasiswa. J Kesehat Masy Nas 2009; 4: 78-83.

12. Huda QA, Andrias DR. Sikap dan perilaku membaca informasi gizi pada label pangan serta pemilihan pangan kemasan. Media Gizi Indones 2016; 11: 175-181.

13. Ollberding NJ, Wolf RL, Contento I. Food Label Use and Its Relation to Dietary Intake among US Adults. J Am Diet Assoc 2011; 111: S47-S51.

14. Campos S, Doxey J, Hammond D. Nutrition labels on pre-packaged foods: A systematic review. Public Health Nutr 2011; 14: 14961506.

15. Mediani NV. Pengetahuan, Persepsi, Sikap, dan Perilaku Membaca Label Informasi Gizi pada Mahasiswa. Institut Pertanian Bogor, http://repository.ipb.ac.id/jspui/bitstream/1234 56789/72090/1/I14nvm.pdf (2014).

16. Purnama AS. Hubungan antara Kemampuan Memca Label Informasi Nilai Gizi, Persepsi terhadap Rasa Produk, dan Faktor Lain dengan Kepatuhan Membaca Label Informasi Nilai gizi pada Siswa/i SMK Mandalahayu, Bekasi Tahun 2012. Universitas Indonesia, http://lib.ui.ac.id/file?file=digital/20354823-SAri Sulistyani Purnama.pdf (2012).

17. Devi VC, Sartono A, Isworo JT. Hubungan Antara Karakteristik Individu Dan Pengetahuan Label Gizi Dengan Membaca Label Gizi Produk Pangan Kemasan Pada Konsumen Di 9 Supermarket Wilayah Kota Tangerang Selatan Tahun 2016. J Gizi 2013; 2: $1-12$.

18. Drichoutis AC., Lazaridis P., Nayga RM. Consumers' use of nutritional labels: A review of research studies and issues. Acad Mark Sci Rev 2006; 9: 1-22.

19. Assifa RR. Faktor-Faktor Yang Berhubungan Dengan Perilaku Membaca Label Pangan Pada Siswa Sma Negeri 68 Jakarta Tahun 2012.

20. Darajat N, Bahar H, Jufri NN. Hubungan Kepatuhan Membaca Label Informasi Zat Gizi dengan Kemampuan Memca Label Informasi Gizi pad Ibu Rumah Tangga di Pasar Basah Mandonga Kota Kendari Tahun 2016. J Ilm Mhs Kesehat Masy 2016; 1: 1-11.

21. Nurhasanah AR. Hubungan Persepsi dan Perilaku Konsumen di DKI Jakarta Terhadap Label Gizi Pangan dengan Status Gizi dan Kesehatan. Institut Pertanian Bogor, http://repository.ipb.ac.id/jspui/bitstream/1234 56789/66282/1/I13arn.pdf (2013). 